\title{
WORLD FOOD AND POPULATION
}

$I^{N}$ recent years the British Association for the Advancement of Science has become increasingly aware of the necessity to re-align its activities to meet modern needs. Gone are the days when its annual meeting provided a forum for discoveries, great and small and made within the preceding twelve months, to be disclosed to an expectant world: radio, television and the scientific and technical press are only too anxious to publicize at once whatever discoveries are deemed to have 'news value'. But not only is the lay public bewildered by this bombardment; scientists themselves also find it increasingly difficult to assess the meaning and implications of work other than that in their own, often narrow, specialisms. The annual meetings of the Association have always provided a welcome opportunity for scientists in the many branches to meet one another and to make contact with an interested public. Now the Association is making a determined effort to present a balanced view of scientific progress to a wider audience-through its work with young people, its programmes of lectures at local centres, the new and attractive format of its bi-monthly journal, The Advancement of Science, and in other ways. At the Cardiff meeting a bold new experiment was tried. Coincident with the inauguration on July 1 of the five-year Freedom from Hunger campaign of the Food and Agriculture Organization of the United Nations, the Association chose as a central theme, to be emphasized by as many sections as wished, the numerous aspects of population pressure on land resources. A complete innovation was the suspension of all sectional programmes for one whole day-Monday, September 5-in favour of two plenary sessions of the entire Association in the Sophia Gardens Pavilion, devoted to a symposium on "World Food and Population".

Some 2,000 members assembled to hear the president, Sir George Thomson, open the proceedings. He reminded the audience that it was the success of medical science that necessitated a falling birth-rate to match the falling death-rate. It was not right that scientists should pass the problem to the politicians who, in any event, had to deal with the toughest and most resistant material in the world, human nature.

Dr. Norman C. Wright, deputy-director general of the Food and Agriculture Organization, presented the facts of the world food situation as they are known to that Organization. He drew a distinction between under-nutrition and malnutrition, and gave reasons for using calorie intake as a measure of undernourishment. What proportion of the world's people can be described as under-nourished clearly depends on the standard taken. While British conditions suggest that 2,800 calories a day are necessary for the development of full health and vigour, requirements for the peoples of tropical climates, with lower average body-weights and stature, are clearly less. But 60 per cent of the world's population appear to have an intake of less than 2,200 calories, of which nearly half have less than 2,000 calories a day. With a poor harvest, under-nutrition passes very easily into semi-starvation and loss of mental alert- ness, and even moral standards. Malnutrition accompanies under-nutrition, but is also found when the intake, though adequate in amount, is derived from an insufficiently varied diet-especially a shortage of protein from an all-cereal diet. Such malnutrition is reflected in the presence of several deficiency diseases-notably kwashiorkor-liable to affect children after weaning, that is, when they are transferred from a milk to a cereal diet. Dr. Wright urged that neither distribution of food surpluses from countries such as the United States nor a world-wide adoption of vegetarian diets could solve the problem-only the widespread and rapid application of recent scientific and technical advances.

Sir Alexander Fleck took up the latter point in the afternoon. Apart from advances in all kinds of techniques constantly being made, there is an adequate body of knowledge, and has been for many years, to secure sufficient food, indeed abundant food, for all mankind if only that knowledge is applied. There are six ways of producing more food: by extending the area under cultivation, substituting more suitable crops or varieties and animals or breeds, providing more water, more nutrients, adopt ing better techniques, and increasing efficiency of crop or animal use. A comparison of present-day yields, for example, between Japan and India in rice shows at once the enormous possibilities to be achieved by providing crops with adequate nutrients and water.

Both Sir Alexander and Prof. H. D. Kay-obviously through his extensive practical experience in recent years in many countries-..stressed the human aspects of the problem: how to get right to the peasant cultivator to help him to help himself. The missionary spirit and the sense of dedication to a cause is nothing new to the British: both are badly needed to-day. Equally vital is the need to convert governments and administrations to the necessity for constructive agricultural policies. Too often agriculture is a Cinderella among government departments.

Prof. David Glass, speaking on the present trends of world population, stressed the double importance of focusing attention on the remainder of the present century, since by 2000 A.D. world population is most likely to increase to more than $6,000,000,000$. Because of the present age-composition of the population in the less-developed countries, even such sharp reduetions in fertility as might result from a rapid spread of birth control would not prevent very considerable increase in numbers by the end of the century. Even with a 50 per cent fall in live births in India during 1956-81, the population would still increase by more than 200 million by 1986. At present the evidence does not justify an assumption of a general fall in fertility: it is more realistic to plan for an increase of world population at the rate of at least I.6 per cent per annum. Prof. Glass considered that we must be prepared for a very massive underpinning of planned economic and social development. Although he included emigration among the measures to be included, he noted that the present increase in world population in one year is about equal to the 
net oversea migration from Europe in the 150 years 1800-1950. He noted, however, the symbolic value of emigration in promoting also economic and social change. In view of the relative ease of increasing food output in Western lands in mid-latitudes, the planned disposal of food surpluses in the West may be no less essential than the raising of agricultural productivity in less-developed regions.

Prof. Arthur Lewis, recently elected to the office of principal of the University College of the West Indies, discussed economic conditions for greater output under the four main headings of incentives, knowledge, capital and organization. He placed expanding demand first among incentives : rising standards of living in the towns demanding more food and more expensive foods. Provided the fruits of the farmer's labours accrue to him and not to the middle man or landlord, he doubted the importance of price stability, preferring freedom of prices to rise. Prof. Lewis was insistent on the enormous capital requirements needed in farming, but some of his assertions regarding organization can be questioned. In his own summary he asserted, "in most of Asia, where labour is abundant, mechanization eontributes only where it brings under the plough land which could not otherwise be cultivated, or makes possible more crops in a year. Mechanization has more to contribute to the under-populated parts of Africa". He advocated subdivision of large properties, especially in Latin America, and considered that compulsion should be used when farmers are too ignorant and conservative to use better sceds or improved cultural practices, and advocated collectivization where necessary. As a West Indian who has a wide experience in many lands, it is interesting that Prof. Lewis more than any other speaker should advocate such forceful methods.

Prof. Dudley Stamp, speaking on land use and food production, stressed the contrast betwoen a popula. tion not only increasing at an unprecedented ratein excess of $45,000,000$ a year-but also with rising standards of living, which meant both more and more varied food, more spacious layout of homes, facilities for recreation and movement and other extensive demands on land, with the known, fixed and broadly inextensible extent of the Earth's land surface which had to satisfy those many demands. While any part of the Earth's surface may have an economic importance through the occurrence of minerals, or for othor reasons, the ecumene or habitable surface of the Earth having sufficient heat, moisture and soil to produce crops to support human lifo, is of limited cxtent. A fifth of the surface is too cold, a fifth too arid, a fifth too mountainous and a tenth soilless, so that only 30 per cent is potentially cultivable even if the many hazards of soil management in the tropics are overcome : at present each of the world's $2,900,000,000$ inhabitants has a share of about $12 \cdot 5$ acres, or 4 acres 'potentially cultivable'. Of this, $1 \cdot 1$ or $1 \cdot 2$ acre is cultivated. Equating non-food crops with the contribution in food from the great open grasslands, it takes the produce of rather more than 1 acre to feed one human being. Against this world yardstick, extreme contrasts can be seen between one country and another-ranging, for example, from Canada with 140 acres a head, $21 \cdot 5$ officially classed as cultivable, with 3.5 used, or the United States $(12 \cdot 5$, about $6,3 \cdot 0)$ to England and Wales $(0 \cdot 8,0 \cdot 6$, 0.55 ) and Japan, where the food has to be wrested from a cultivated acreage of 0.17 acre a head. In some countries it is clear that concentration on high-calorie foodstuffs and intensive cultivation is a national first priority; in most countries comprehensive land planning is the only sonsible approach to the problem. Such planning must be based on objective surveys and mapping of existing land use (hence the importance of the world-wide scheme of the World Land Use Survey of the International Geographical Union) with an attempt to understand the reason for the present position and trends.

Prof. Stamp advocated further attempts to rate land of different types according to potential productivity and compared actual production by using a Standard Nutrition Unit of $1,000,000$ calories farm production per annum (equivalent to a food intake of 2,460 por day) pointing out that 'carrying capacity of land' varies in even leading countries from less than $0 \cdot 3$ to 7 such units an acre. He appealed especially for fresh thinking in many directions, and by the many different sciences which have contributions to make. In particular he pointed out the fallacy of discussing 'over-population' unrelated to standards of farming technique-Britain has been over-populated at least since Norman times. A maximum population which could be supported is very different from the small body of experts which might most effectively produce the food. In erosion and flood control more emphasis should be placed on trapping and distributing eroded material where it could provide useful land. While it is desirable to preserve naturally good agricultural land and provide conditions where the microfauna and microflora can do their work without cost, why should not modern earth-moving machinery over large areas mix sterile sands and intractable clays to the right texture to receive the chemist's nutrients?

In the afternoon, after Sir Alexander Fleck and Prof. Kay had spoken, eight or nine speakers who had previously given in their names took part in a general discussion before Prof. P. M. S. Blackett wound up. Ritchie Calder remarked on the historic significance of the occasion-perhaps the first time in 129 years that the Association as a whole had got together to debate a problem of world-wide importance. Science had provided a vast super-market of knowledge : the user must have a thought-out shopping list. The common tacit assumption of the economists that efficiency in farming is to be equated with large-scale monoculture was voiced by Colin Clark, and brought vigorous headshaking from Dr. Kay; further, he doubted whether protein deficiency is widespread and whether many of the policies of the Food and Agriculture Organization are right-especially any encouragement of small-scale intensive mixed farm. ing. Mr. James Callaghan, M.P., sharply reminded tho Conference that a 5 per cent increase on prices paid for the agricultural raw materials of tho 'underdeveloped' lands more than equalled all 'aid' : guarantee their prices and forget 'aid'. Sir Charles Darwin felt that only part of the problem is being considered : man is an animal and behaves as such. With plenty of space there has been unparalleled expansion for two hundred years-the struggle for existence must come. Birth control may stave off the evil day, but is it not possible, he askod, that those who have believed in birth control would be the ones to go under? Prof. Sargant Florence, however, held that we do not want just to keep alive, but at a proper standard: we must increase production, but decrease reproduction. 
In his summing-up, Prof. Blackett stressed four points: first, nothing we can do, short of nuclear warfare, can alter the fact that a great increase in population is inevitable in the near future; secondly, the technical 'know-how' exists; thirdly, there must be initiative and 'crash-action; fourthly, the educational aspect is vital and we should open the doors of our universities and technical colleges, however difficult it may be, more widely to overseas students. Finally, he felt that the day's useful discussions had ended on a note of restrained but robust optimism.
L. Dudley Stamp

\section{AFFORESTATION OF INDUSTRIAL WASTE}

$\mathrm{T}$ HE sight of derelict land is all too familiar in the industrial areas of Great Britain, and the purpose of the session which was held in Sub-section $\mathrm{K}^{*}$ (Forestry) of the British Association on September 2 in Cardiff was to explore the possibilities of afforestation as a land-use tool to improve the amenities of such areas. The three speakers looked at the problem from different points of view : that of a Forestry Commission officer, a planning officer of a county council, and a land agent to an owner of substantiall areas of ironstone workings. It was refreshing to find that there was a large measure of agreement between all three as to where and in what circumstances afforestation could be usefully employed.

The symposium was opened by J. Q. Williamson of the Forestry Commission with a review of the evidence which has been built up over the past fifty years on the planting of trees on colliery spoil heaps. In his opinion the earlier doubts as to the success of such planting because of the probable lack of fertility of such apparently sterile sites has proved groundless. A large range of tree species can be planted successfully on tips so long as certain precautions are observed. The choice of planting species must first be governed by local conditions, particularly by the smoke pollution factor, which may rule out all conifers. Exposure is of great importance in tree growth generally, and the miniature mountains created by many spoil heaps could lead to severe exposure, especially if the heap happened to be already in an exposed position.

In areas where there is atmospheric pollution, birch, alder, sycamore, and in more fertile sheltered areas, ash and poplar, were recommended by $\mathrm{Mr}$. Williamson as the most likely to succeed. Where tips are situated in more rural areas, over which the atmosphere is purer, conifers can also be grown, and this is much more attractive from the economic point of view. Of the conifers, Corsican and Austrian pine are usually to be preferred, but Japanese larch and Scots pine can also do well. His experience has shown that there is no special difficulty in establishing such species by normal forestry methods, but the trees must be looked after. Grazing animals must be rigorously excluded from the young plantations and, most important of all, the local population must be taught to cherish the young trees. Most failures in the past have been due to vandalism, and it is almost a waste of time to embark on a planting scheme unless there is a determined effort to guard the trees from damage during their early years. He recommended. strongly that a programme of forestry education for the local population should accompany the planting of any colliery spoil heap, and if possible the local school children should be encouraged to take part in the actual planting and to look on the resulting woods as their own.
Mr. Williamson then gave details of the experimental afforestation of an open-cast coal site in Coed Morgannwg. He pointed out that by applying a restoration specification, which did not entail levelling and restoration of the top soil, a great deal of money can be saved. The result of this work had been most encouraging, and of the species used Corsican pine, Lawson cypress and Japanese larch among the conifers and common alder, grey alder and false acacia among the hardwoods had grown well. The trees on the more porous slopes had grown better than on the level ground where the passage of heavy machines had led to compaction of the soil.

After this technical appraisal of the problem, it was encouraging to learn from Mr. J. Casson, of the Planning Department of the Lancashire County Council, that the extensive work of afforestation carried out by his Department over the past nine years has led him to the same conclusions. $\mathrm{He}$ considers that there are thousands of acres in Lancashire alone which could be afforested with comparative ease and at not much, if any, greater expense than that incurred in establishing forest crops on normal sites. It is unfortunate that not many planning authorities in England and Wales have yet made use of Section 89 of the National Parks and Access to the Countryside Act of 1949 to undertake planting work aimed at enhancing the countryside. $\mathrm{He}$ considers that while the main objective of such a planting programme is the improvement of amenities, this work could obviously, to a greater or lesser degrea, make a contribution to the economy of any area where forestry operations could be successfully carried out. The effect of enhanced amenities in checking emigration and attracting new industry could well be valuable in arresting economic decline; the converse is undoubtedly true-ugliness leads to emigration and discourages new industrial development. He looked on the work done in Lancashire up to the present as being mainly a fact-finding exercise to see how far forestry operations are practicable under various conditions of difficulty (climate, soil, pollution, etc.). They have located their siting in significant localities as experiments, not only in forestry, but also in the use of forestry as an instrument of land-use policy in the overall physical and economic rehabilitation of depressed and damaged regions. His Council's policy has been to acquire or plant under agreement without resort to compulsory purchase. While there is a wide choice of sites which might be planted in Lancashire, it is significant that land acquisition rather than technical difficulties has been the greatest problem in planning a forward programme. For every 100 acres planted, investigations and negotiations have been opened for 200-300 acres which have had to be 